\title{
Evaluation of the Antioxidant Activity of the Polyherbal (Conocarpus lancifolius L., Capparis spinosa L. and Dodonaea viscosa) Extracts and Assessment of the Hypoglycaemia Effect in Diabetic Mice
}

\author{
Nawras A. Kadim ${ }^{1}$, Ahmed H. AL-Azawi ${ }^{2}$, Alaa A. Abdulhassan ${ }^{3}$, Warqaa Y. Salih ${ }^{4}$ \\ ${ }^{1}$ M.Sc. Student, ${ }^{2}$ Assistant Professor, ${ }^{3}$ Lab. Technical, ${ }^{4}$ Assistant Lecturer, Biotechnology Dept., Genetic \\ Engineering and Biotechnology Institute for Post Graduate Studies, University of Baghdad, Baghdad, Iraq
}

\begin{abstract}
Diabetes mellitus, often referred to simply as diabetes, is a chronic metabolic disorder due to the relative deficiency of insulin secretion and varying degrees of insulin resistance. It is characterised by high circulating glucose. Excessive levels of either molecular oxygen or Reactive Oxygen Species (ROS) lead to an imbalance in the body's normal oxidative metabolism that to leads to high glucose levels in the blood (hyperglycaemia), resulting in metabolic disturbances (oxidative stress) and chronic complications in diabetes. The present study aims to estimate the antioxidant activity in diabetic mice induced via alloxan of a combination of three types of plant leaves (Conocarpus lancifolius L., Capparis spinosa L. and Dodonaea viscosa). The total phenolic content using Folin-Ciocalteu reagent and the antioxidant activity utilizing 2, 2-diphenyl1-picrylhydrazyl (DPPH) assay were estimated. The effect of polyherbal formulation leaves extracts on serum glucose level was done on forty-two albino mice divided into six groups and treated with polyherbal extracts and metformin. The results of total phenolic content in the polyherbal leaves extracts was observed $(15.52 \mathrm{mg} \backslash \mathrm{g})$ in the aqueous extracted samples, while the total phenolics content was $(46.97 \mathrm{mg} \backslash \mathrm{g})$ in the methanolic extract, and the antioxidant activity showed the methanolic extract was the highest free radical scavenging activity (93.28\%) than the aqueous extract $(86.77 \%)$ in $10 \mathrm{mg} / \mathrm{ml}$ and approach to the artificial antioxidant Butylated hydroxytoluene (BHT) which was (93.67\%). This study showed both extracts of polyherbal leaves did not induce lethality in mice when administered orally at a dose of $2000 \mathrm{mg} / \mathrm{kg}$. on the other hand, Diabetic mice treated with methanolic extract at doses $200 \mathrm{and} 400 \mathrm{mg} / \mathrm{kg}$ showed a significant decrease $(\mathrm{p}<0.01)$ in serum glucose level after 35 days, which was 113.66 and $107.66 \mathrm{mg} / \mathrm{dl}$ respectively, and the aqueous extract was 124.66 and $117.00 \mathrm{mg} / \mathrm{dl}$ respectively when compared with the control positive group $(324.00 \mathrm{mg} / \mathrm{dl})$.
\end{abstract}

Keywords: polyherbal, total phenol, antioxidant, hypoglycaemia, diabetic mice.

\section{Introduction}

Diabetes mellitus is a non-infectious endocrine disorder which is characterized by the disturbance in the metabolism of carbohydrates and associated with hyperglycaemia ${ }^{1}$. It is linked with the developing

Corresponding author:

Ahmed H. AL-Azawi

ahmed@ige.uobaghdad.edu.iq of various serious diseases like micro-vascular (nephropathy, retinopathy, nephropathy) and macrovascular (peripheral vascular disease and coronary heart diseases $)^{2,3}$. Diabetes mellitus is known as diabetes which was observed as diseases related to "sweet urine" and muscle loss. Glucose blood levels are maintained by insulin which is a hormone released from the pancreas. When these level increases, insulin is produced from the pancreas and maintained the level of glucose. In diabetic patients, the production of insulin is absent or less which causes hyperglycaemia ${ }^{4}$. 
Treatment of Diabetes mellitus without any adverse effects is still the biggest question for medical practitioners. Medicinal plants containing secondary metabolites such as phenolic, anthocyanin, and flavonoids compounds have been used as alternative therapeutic tools to treat many diseases throughout medical history. Several types of plant extracts or plantderived molecules have been investigated for their potential as antioxidant sources against several diseases $5,6,7$. In addition, plant-based natural antioxidants are preferred to synthetic ones due to their good safety profiles ${ }^{8}$. Therefore, there is growing interest in finding natural compounds that could prevent oxidative damage underlying the pathogenesis of many diseases ${ }^{9}$. The aim of the study is to assessment of the efficiency of polyherbal leaves extracts as antioxidant in diabetic mice induced via alloxan.

\section{Materials and Methods}

\section{Chemical reagents}

The chemical reagents DPPH (2,2-diphenyl-1picrylhydrazyl), Butylated hydroxytoluene (BHT), ascorbic acid, gallic acid monohydrate (3,4,5trihydroxybenzoic acid), sodium carbonate and metformin were purchased from Sigma aldrich chemicals (Sigma-Aldrich, Germany ). Folin Ciocalteu reagent was purchased from Merck (Darmstadt, Germany), alloxan (BDH, England).

\section{Collection of plants}

Three species of plant leaves were collected from the trees in the gardens of the University of Baghdad. The plant leaves were identified as (Conocarpus lancifolius L., Capparis spinosa L. and Dodonaea viscosa) by the specialist, Department of Biology, College of Science, University of Baghdad. The plant leaves washed with water to remove the dust and soil deposits and dried at room temperature until complete removal of moisture content, each dried plants were crushed using a grinder and stored at $-20^{\circ} \mathrm{C}$ for further analysis.

\section{Polyherbal preparation}

The polyherbal leaves extract was prepared by mixing the dried extracts of the plant leaves (Conocarpus lancifolius L., Capparis spinosa L. and Dodonaea viscosa) in the ratio of 1:1:1 respectively.

\section{Preparation of aqueous extract}

Water extract was prepared according to N'Guessan et al. ${ }^{10}$, macerated 100 grams of plant leaves residue in $700 \mathrm{ml}$ of distilled water for 72 hours with continuous shaking. Then the mixture was vacuum filtered through Whitman No. 1 paper. The filtrate evaporated to dryness under vacuum at $50^{\circ} \mathrm{C}$ by a rotary evaporator to eliminate water. The resulting extract stored in amber glass vials at $4{ }^{\circ} \mathrm{C}$ until analyzed.

\section{Preparation of methanolic extract}

The methanolic extract was prepared according to AACC ${ }^{11}$ by using a Soxhlet apparatus. 100 grams of plant leaves residue was put in a thimble and $700 \mathrm{ml}$ of $70 \%$ methanol was added within $40-60{ }^{\circ} \mathrm{C}$ for 6 hours. The solution was filtered through a filter paper Whitman No. 1 and evaporated to dryness under vacuum at $40^{\circ} \mathrm{C}$ by a rotary evaporator to get rid of methanol; the extract was stored in amber glass vials at $4{ }^{\circ} \mathrm{C}$ until analyzed.

\section{Determination of total phenolic contents}

Total phenolic content of Moringa oleifera extracts were determined spectrophotometrically using the FolinCiocalteu method described by ${ }^{12} .2 \mathrm{ml}$ of Folin-Ciocalteu reagent (diluted 10 times) was mixed with $1.6 \mathrm{ml}$ of $7.5 \%$ sodium carbonate solution and $0.4 \mathrm{ml}$ of Moringa oleifera extracts. The volume was completed to $5 \mathrm{ml}$ by adding distilled water. The tubes were covered with parafilm for $30 \mathrm{~min}$. at room temperature, and then the absorbance was read at $760 \mathrm{~nm}$ spectrophotometrically.

\section{Evaluation of the Antioxidant activity DPPH} assay

According to Ogunmoyole et al. ${ }^{13}$, the antioxidant activity of the prepared polyherbal methanolic and aqueous leaves extracts was conducted. $5 \mathrm{ml}$ of a freshly prepared $0.004 \%$ of 2,2-diphenyl-1-picrylhydrazyl $(\mathrm{DPPH})$ in methanol was mixed with $50 \mu \mathrm{l}$ of different concentrations $(0.625,1.25,2.5,5$ and 10$) \mathrm{mg} / \mathrm{ml}$, which were prepared by dissolving 0.1 gram of the polyherbal extract in distilled water then the volume was completed into $10 \mathrm{ml}$ to make the working solution $10 \mathrm{mg} / \mathrm{ml}$, and 
serial two-fold dilutions of the polyherbal extract were prepared to make the concentrations $10-0.625 \mathrm{mg} / \mathrm{ml}$. The absorbance of each dilution, after 30 minutes, was measured at $517 \mathrm{~nm}$. Butylated hydroxytoluene (BHT) and vitamin $\mathrm{C}$ were used as a positive control. All tests were performed in triplicate. The percentage DPPH reduction (or DPPH radical scavenging capacity) was calculated as:

$$
\begin{aligned}
& \% \text { Reduction }=(\text { Abs DPPH }- \text { Abs Dil. }) / \text { Abs DPPH } \\
& \times 100
\end{aligned}
$$

Where:

Abs DPPH $=$ average absorption of the DPPH solution

Abs Dil. $=$ average absorption of the three absorption values of each dilution.

With the obtained values, a graphic was made using Microsoft Excel. The $\mathrm{EC}_{50}$ of each extract (concentration of extract or compound at which reduced $50 \%$ of DPPH) was taken from the graphic.

\section{Experimental animals}

Forty-Two male albino mice weighing 27-32 grams were obtained from Biotechnology Research Center, Al- Nahrain University. They were kept in standard conditions, the temperature about $22{ }^{\circ} \mathrm{C}, 12$ hours light/dark cycle. They were left for two weeks for acclimatization with the experimental conditions. Standard pellet diet and water were provided daily.

\section{Determination of acute toxicity of polyherbal} extracts

Acute toxicity of the polyherbal preparation was carried according to the guidelines set by the Organization for Economic Co-operation and Development (OECD), revised draft guidelines 423 . A group of 30 adult healthy albino mice of either sex weighing 27-32 grams was divided into five groups (six mice / group) for each extract (aqueous and methanolic). All groups were treated orally with doses of 100, 250, 500, 1000 and $2000 \mathrm{mg} / \mathrm{kg}$ of polyherbal preparation to study the acute toxicity. The animals were then observed for 3 hours for general behavioural, neurological, and autonomic profiles and every $30 \mathrm{~min}$ for the next 3 hours and finally for mortality after 24 hours ${ }^{14}$.

\section{Selection of doses}

To estimation the antidiabetic activity, two-dose levels were chosen (200 and $400 \mathrm{mg} / \mathrm{kg}$ body weight) in such a way that the first dose was approximately onetenth of the maximum dose during acute toxicity studies and the second high dose was twice of the first dose.

\section{Induction of experimental diabetes}

Blood glucose levels (baseline) were tested before the treatments. Diabetes was induced in all mice (except normal control group) by a single dose of alloxan monohydrate (150 mg/kg body weight) intraperitoneally to overnight fasted mice. After 1 hour of alloxan administration, the animals were fed with standard pellets and water. Seventy-two hours later of alloxan administered, blood glucose was measured by glucometer which was collected from the tail vein from the mice. Mice showing fasting blood glucose levels $(>250 \mathrm{mg} / \mathrm{dl})$ were selected for the study ${ }^{15}$.

\section{Evaluation of the antidiabetic activity of the polyherbal extracts}

The Diabetic mice were randomly divided into seven groups with six animals in each group. The single dose of each extract and drug was administered once daily by oral for 35 days continuously as follows:

Group 1: This group served as a negative control in which the mice received normal feed and distilled water.

Group 2: This group was a positive control for alloxan (150 mg/kg BW).

Group 3: Diabetic mice of this group treated with standard drug metformin (150 mg/kg BW/day).

Group 4: Diabetic mice of this group treated with the polyherbal methanolic extract (200 mg/kg BW/day).

Group 5: Diabetic mice of this group treated with the polyherbal methanolic extract (400 mg/kg BW/day).

Group 6: Diabetic mice of this group treated with the polyherbal aqueous extract (200 mg/kg BW/day). 
Group 7: Diabetic mice of this group treated with the polyherbal aqueous extract (400 mg/kg BW/day).

\section{Collection of Blood}

Every week blood glucose levels were measuring. The blood samples were collected from the tail vein of each mice of the group as a drop. The drop was then immediately placed on the strip of the glucometer to find the glucose level quickly.

\section{Statistical Analysis}

The Statistical Analysis System-SAS program 16 was used to detect the effect of difference factors in study parameters. Least significant difference-LSD test was used to significant compare between means in this study.

\section{Results and Discussion}

Total phenolic content of polyherbal leaves

\section{extracts}

The polyherbal leaves extracts were evaluated by using Folin-Ciocalteu reagent for the determination of total phenolic contents. The results showed that the methanolic extract had the highest total phenolic content than the aqueous extract as shown in Table (1). Polyphenols are known for their strong antioxidant properties, their activity is based on scavenging free radicals and reactive oxygen/nitrogen species, the reduction of oxidized intermediates, metals binding (mainly iron and copper), the inhibition of enzymes responsible for the formation of free radicals (oxidase, peroxidase), the activation of antioxidant enzymes (catalase, superoxide dismutase) and the prevention of oxidation of other antioxidants (ascorbic acid, vitamin E) ${ }^{17}$.

Table 1: Total phenolic content of polyherbal leaves extract

\begin{tabular}{|c||c||c||c||}
\hline $\begin{array}{c}\text { Concentration } \\
(\mathbf{m g} \backslash \mathbf{m l})\end{array}$ & $\begin{array}{c}\text { Aqueous extract } \\
(\mathbf{m g} \backslash \mathbf{g})\end{array}$ & $\begin{array}{c}\text { Methanolic extract } \\
(\mathbf{m g} \backslash \mathbf{g})\end{array}$ & LSD value \\
\hline \hline $\mathbf{2 . 5}$ & $3.96 \pm 0.07$ & $12.98 \pm 0.11$ & $0.221 * *$ \\
\hline \hline $\mathbf{5}$ & $8.17 \pm 0.06$ & $24.88 \pm 0.23$ & $0.679 * *$ \\
\hline \hline $\mathbf{1 0}$ & $15.52 \pm 0.24$ & $46.97 \pm 0.07$ & $0.692 * *$ \\
\hline \hline LSD value & $0.498^{* *}$ & $0.513^{* *}$ & $\cdots$ \\
\hline \hline \multicolumn{4}{|r|}{$* *(\mathrm{P} \leq 0.01)}$. \\
\hline
\end{tabular}

\section{Antioxidant activity of polyherbal leaves extracts (DPPH assay)}

In this study, the radical scavenging activity of each extract was compared at concentrations of $(0.625$, $1.25,2.5,5$ and 10) $\mathrm{mg} / \mathrm{ml}$. BHA and vitamin $\mathrm{C}$ were used as references. The results showed that the free radical scavenging activity of methanolic extracts was $(93.189 \%)$ in $10 \mathrm{mg} / \mathrm{ml}$ was more effective than aqueous extracts $(86.77 \%)$ in the same concentration, and It was approach with the natural antioxidant (vitamin C) and artificial antioxidant (BHT) which was $(96.40 \%$ and $93.67 \%$ ) respectively As shown in Table (2).
Furthermore, the antioxidant activity is expressed as an Effective Concentration $\left(\mathrm{EC}_{50}\right)$. The half maximal Effective Concentration $\left(\mathrm{EC}_{50}\right)$ are often refers to the concentration of a drug, toxicant or antibody which induces a response half way between the baseline and maximum after a specified exposure time, it commonly used as a measure of potency of a drug ${ }^{18}$.

The radical scavenging capacity $\left(\mathrm{EC}_{50}\right)$ of methanolic and aqueous extracts were found to be (1 and $1.35 \mathrm{mg} / \mathrm{ml}$ ) respectively, and the value of BHT and V. $\mathrm{C}$ were found to be $(0.60$ and $0.47 \mathrm{mg} / \mathrm{ml})$ respectively (Figure 1). The effectiveness of the antioxidant properties is inversely correlated with $\mathrm{EC}_{50}$ values. Lee 
et al., ${ }^{19}$ reported that if the $\mathrm{EC}_{50}$ value of an extract is less than $10 \mathrm{mg} / \mathrm{ml}$, it indicates that the extract is an effective antioxidant. The $\mathrm{EC}_{50}$ value of polyherbal leaves extracts were less than $10 \mathrm{mg} / \mathrm{ml}$, and this indicates that the extracts were an effective antioxidant.

Table 2: Radical scavenging activity of polyherbal leaves extract

\begin{tabular}{|c||c||c|c|c|c||}
\hline $\begin{array}{c}\text { Concentration } \\
\text { mg } \backslash \mathrm{ml}\end{array}$ & $\begin{array}{c}\text { Aqueous } \\
\text { extract }\end{array}$ & $\begin{array}{c}\text { Methanolic } \\
\text { extract }\end{array}$ & BHT & Vit. C. & LSD value \\
\hline \hline $\mathbf{0 . 6 2 5}$ & $20.86 \pm 0.16$ & $36.31 \pm 0.12$ & $60.68 \pm 0.26$ & $90.23 \pm 0.19$ & $0.596^{* *}$ \\
\hline \hline $\mathbf{1 . 2 5}$ & $51.34 \pm 0.05$ & $68.52 \pm 0.17$ & $81.42 \pm 0.24$ & $91.54 \pm 0.29$ & $0.698^{* *}$ \\
\hline $\mathbf{2 . 5}$ & $57.92 \pm 0.03$ & $80.17 \pm 0.03$ & $91.28 \pm 0.04$ & $95.23 \pm 0.16$ & $0.288^{* *}$ \\
\hline $\mathbf{5}$ & $85.48 \pm 0.06$ & $92.27 \pm 0.02$ & $93.13 \pm 0.01$ & $96.21 \pm 0.16$ & $0.284^{* *}$ \\
\hline \hline $\mathbf{1 0}$ & $86.77 \pm 0.06$ & $93.28 \pm 0.02$ & $93.67 \pm 0.01$ & $96.40 \pm 0.27$ & $0.459 * *$ \\
\hline \hline LSD value & $0.196 * *$ & $0.309 * *$ & $0.519 * *$ & $0.710^{* *}$ & $\cdots$ \\
\hline
\end{tabular}

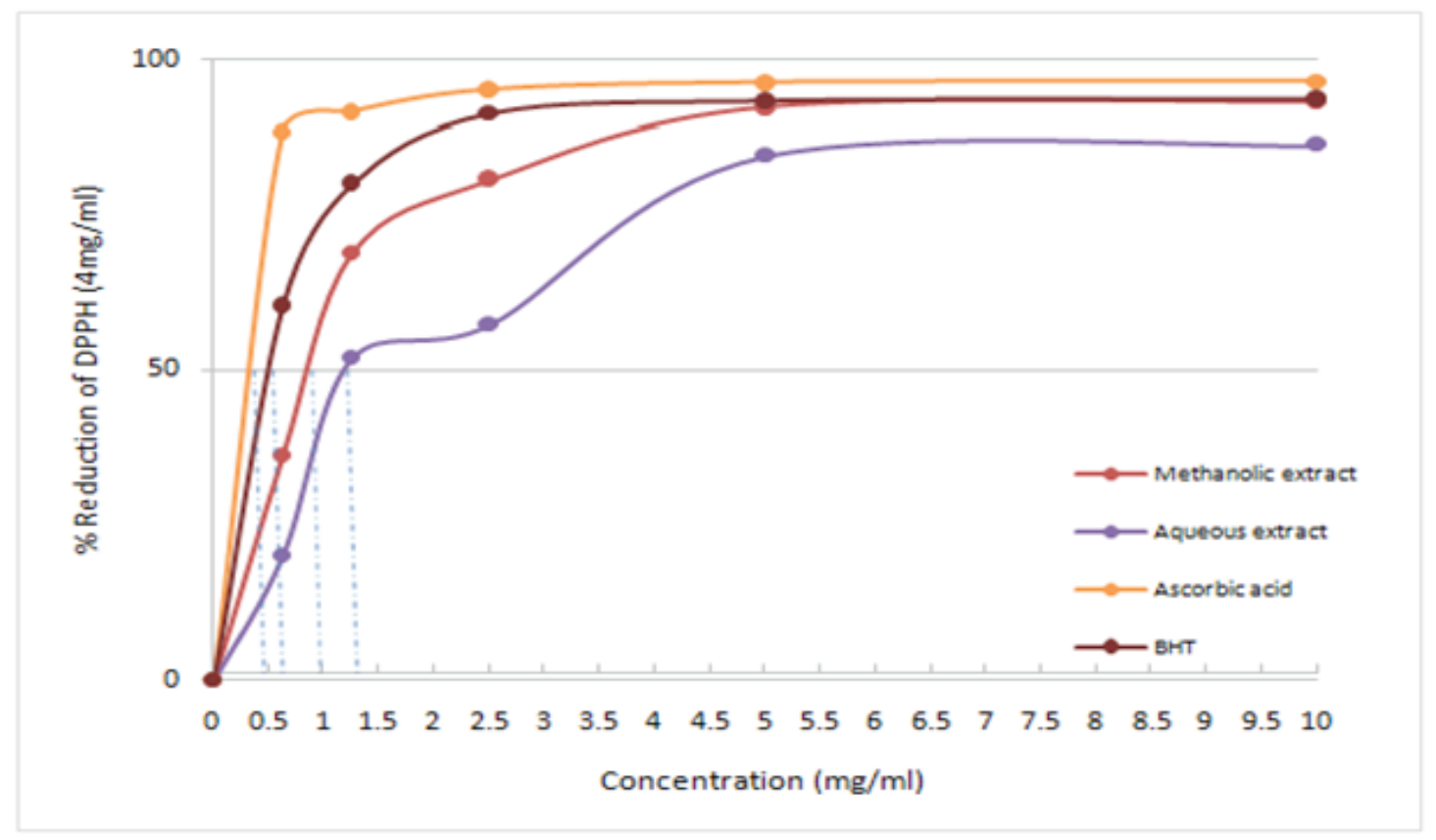

\section{Figure 1: $\mathrm{EC}_{50}$ of polyherbal leaves extracts}

\section{Acute toxicity test}

The study of the acute toxicity of polyherbal leaves extracts shows different signs when treated with different oral doses of aqueous and methanolic extract (Table 3). The experimental mice show appreciable changes in physical activity and shown abnormal responses such as Tacky cardiac, increase breathing, sedation and animal tend to loneliness for one side in different time in dose $2000 \mathrm{mg} / \mathrm{kg}$, but there is no mortality in mice were recorded after 24 hours post treatment. The results showed that the aqueous and methanolic extract of polyherbal leaves practically non toxic according to Hodge and Sterner ${ }^{20}$. Accordingly, to this study, both extracts of polyherbal leaves did not induce lethality in mice when administered orally at doses of began from 100 till reach to $2000 \mathrm{mg} / \mathrm{kg}$. This result suggests that $\mathrm{LD}_{50}$ of the extract would be greater than $2000 \mathrm{mg} / \mathrm{kg}$. Therefore, the plant extract can be assumed practically non-toxic. 
Table 3: Acute toxicity and mortality rate of polyherbal leaves extracts

\begin{tabular}{|c|c|c|c|}
\hline $\begin{array}{c}\text { Dose of extract } \\
\mathrm{mg} / \mathrm{kg} / \mathrm{B} . \mathrm{W}\end{array}$ & $\begin{array}{l}\text { No. of mice } \\
\text { per group }\end{array}$ & $\begin{array}{l}\text { No. of dead/ } \\
\text { No. of animal }\end{array}$ & $\begin{array}{c}\text { Sign of animal treated with } \\
\text { extract }\end{array}$ \\
\hline \multicolumn{4}{|c|}{ Aqueous extract } \\
\hline 100 & 6 & $0 / 6$ & Nil \\
\hline 250 & 6 & $0 / 6$ & Nil \\
\hline 500 & 6 & $0 / 6$ & Nil \\
\hline 1000 & 6 & $0 / 6$ & $\begin{array}{c}\text { Tacky cardiac, increase breathing, } \\
\text { sedation and animal tend to } \\
\text { loneliness for one side in different } \\
\text { time }\end{array}$ \\
\hline 2000 & 6 & $0 / 6$ & $\begin{array}{l}\text { Tacky cardiac, increase breathing, } \\
\text { sedation and animal tend to } \\
\text { loneliness for one side in a different } \\
\text { time but it takes a long time than } \\
\text { above }\end{array}$ \\
\hline \multicolumn{4}{|c|}{ Methanolic extract } \\
\hline 100 & 6 & $0 / 6$ & Nil \\
\hline 250 & 6 & $0 / 6$ & Nil \\
\hline 500 & 6 & $0 / 6$ & Interrupted sedation \\
\hline 1000 & 6 & $0 / 6$ & $\begin{array}{l}\text { Tacky cardiac, titanic hair skin, } \\
\text { animal tend to loneliness for one } \\
\text { side in different time }\end{array}$ \\
\hline 2000 & 6 & $0 / 6$ & $\begin{array}{l}\text { Tacky cardiac, titanic hair skin, } \\
\text { animal tend to loneliness for one } \\
\text { side in different time all these signs } \\
\text { take a long time than above }\end{array}$ \\
\hline
\end{tabular}

\section{Effect of polyherbal leaves extracts on serum} glucose level

At the beginning of the experiment, the blood glucose of animals was measured as the (Baseline), after that all animal were injected with alloxan to induce Diabetes (except normal group) and then divided to seven groups and treated with polyherbal leaves extracts and metformin as shown in (Table 4 ). The results showed that diabetic mice treated with methanolic extract at doses 200 and $400 \mathrm{mg} / \mathrm{kg}$ (group 4 and 5) was significant gradual descent decreased $(p<0.01)$ in the serum glucose level after 35 days, which was 113.66 and $107.66 \mathrm{mg} / \mathrm{dl}$ respectively when compared with control positive groups 324.00 (group 2). Likewise, the results showed that the serum glucose level decreased $(p<0.01)$ in metformin treatment diabetic mice 100.66 (group 3) compared to control positive groups (group 2), which mean the methanolic extract at doses $400 \mathrm{mg}$ / $\mathrm{kg}$ have the same effect of metformin in decrease serum glucose level. Methanolic extracts were more effective than aqueous extracts which was 124.66 and $117.00 \mathrm{mg} /$ $\mathrm{dl}$ in concentrations 200 and $400 \mathrm{mg} / \mathrm{kg}$ (group 6 and 7) respectively. 
Table 4: Effect of polyherbal leaves extracts on serum glucose level

\begin{tabular}{|c|c|c|c|c|c|c|c|c|}
\hline Groups & Baseline & Day 0 & Day 7 & Day 14 & Day 21 & Day 28 & Day 35 & LSD Value \\
\hline Group 1 & $90.66 \pm 1.76$ & $91.33 \pm 1.20$ & $90.00 \pm 3.60$ & $95.33 \pm 0.88$ & $91.33 \pm 1.20$ & $92.00 \pm 3.05$ & $91.00 \pm 2.08$ & $6.63 \mathrm{NS}$ \\
\hline Group 2 & $89.33 \pm 1.85$ & $299.66 \pm 1.20$ & $303.66 \pm 2.84$ & $300.33 \pm 3.48$ & $308.66 \pm 5.60$ & $317.33 \pm 2.60$ & $324.00 \pm 2.65$ & $9.61 *$ \\
\hline Group 3 & $89.33 \pm 2.18$ & $300.00 \pm 2.51$ & $227.66 \pm 1.45$ & $192.00 \pm 1.73$ & $140.33 \pm 0.33$ & $106.66 \pm 2.18$ & $100.66 \pm 0.88$ & $5.36^{* *}$ \\
\hline Group 4 & $91.66 \pm 1.45$ & $302.66 \pm 4.33$ & $244.66 \pm 2.02$ & $211.00 \pm 1.15$ & $152.00 \pm 1.73$ & $127.66 \pm 0.88$ & $113.66 \pm 1.45$ & $6.50 * *$ \\
\hline Group 5 & $90.33 \pm 1.20$ & $300.00 \pm 6.65$ & $231.66 \pm 2.02$ & $201.00 \pm 1.15$ & $145.00 \pm 1.15$ & $120.33 \pm 1.20$ & $107.66 \pm 2.60$ & $8.93 * *$ \\
\hline Group 6 & $88.33 \pm 1.20$ & $296.33 \pm 5.23$ & $257.66 \pm 0.88$ & $228.66 \pm 0.88$ & $165.33 \pm 0.88$ & $139.66 \pm 2.60$ & $124.66 \pm 0.33$ & 7.07 ** \\
\hline Group 7 & $88.00 \pm 1.52$ & $292.66 \pm 3.48$ & $249.33 \pm 1.45$ & $217.00 \pm 1.15$ & $155.66 \pm 2.02$ & $131.66 \pm 1.45$ & $117.00 \pm 2.31$ & $6.22 * *$ \\
\hline LSD Value & $4.95 \mathrm{NS}$ & $12.12 * *$ & $6.71 * *$ & 5.21 ** & $7.44^{* *}$ & $6.48^{* *}$ & 5.89 ** & $\cdots$ \\
\hline \multicolumn{9}{|c|}{${ }^{* *}(\mathrm{P} \leq 0.01)$} \\
\hline \multicolumn{9}{|c|}{$\begin{array}{l}\text { Group 1: Control, } \\
\text { Group 2: Alloxan (150 mg kg), } \\
\text { Group 3: Diabetic mice + Metformin ( } 150 \mathrm{mg} \mathrm{kg}), \\
\text { Group 4: Diabetic mice + Polyherbal methanolic extract }(200 \mathrm{mg} \mathrm{kg}) \text {, } \\
\text { Group 5: Diabetic mice + Polyherbal methanolic extract ( } 400 \mathrm{mg} \mathrm{kg}) \text {, } \\
\text { Group 6: Diabetic mice + Polyherbal aqueous extract }(200 \mathrm{mg} \mathrm{kg}), \\
\text { Group 7: Diabetic mice + Polyherbal aqueous extract }(400 \mathrm{mg} \mathrm{kg}) \text {. }\end{array}$} \\
\hline
\end{tabular}

In the present study, oral administration of polyherbal formulation at dose levels of 200 and $400 \mathrm{mg} / \mathrm{kg}$ for 35 days enhances insulin production. This may be due to the regenerating effect of pancreatic $\beta$-Cells. The polyherbal formulation increased insulin levels in a dose dependent manner and was comparable with that of standard drug ${ }^{21}$. Antidiabetic potential of phytochemicals as Alkaloids produce antihyperglycaemic action by potentiating pancreatic secretion of insulin from $\beta$-cell of islets or by enhancing transport of blood glucose to peripheral tissue 22. According to Ayurveda, there are several medicinal plants that have been identified to possess antidiabetic potential. Most of the herbal preparations from these medicinal plants are reported to have minimal or no side effects ${ }^{23}$. Due to the antioxidant properties of polyphenols, these compounds can play an important role in antidiabetic prevention and therapy ${ }^{24}$. Flavonoids might prove to be important for alternative diabetic treatment, as it helps in preventing $\beta$-cell apoptosis, promoting $\beta$-cell proliferation and insulin secretion, and enhancing insulin activity ${ }^{25}$. Triterpenoid and steroidal glycosides are collectively referred to as saponins; these compounds are known to possess potent hypoglycaemic activity ${ }^{26}$. The phenolic compounds may exhibit their hypoglycaemic activities by increasing the levels of serum insulin, increasing the sensitivity of tissues to insulin action, stimulating the activity of enzymes of glucose utilization and inhibiting the activity of $\alpha$-amylase ${ }^{27}$. Tannins also play an important role in preventing diabetic complications by reducing the formation of advanced glycation end products and oxidative stress ${ }^{28}$.

\section{Effect of polyherbal leaves extracts on body} weight

At present, the treatment of diabetes mainly involves a sustained reduction in hyperglycaemia by the use of hypoglycaemic drugs in addition to insulin. More so, myriads of medicinal plants seem to reveal potential hypoglycaemic activity and antioxidant action with desirable properties ${ }^{29}$. The present study indicated that the final body weight of positive control (diabetes induction) was significantly decreased (23.97 gram) when compared with control negative group 30.26 gram (group 1). Otherwise, the reduction in body weight was partially restored or improved upon administration of 
polyherbal methanolic and aqueous extracts at doses 200 and $400 \mathrm{mg} / \mathrm{kg}$ (groups $4,5,6,7$ ) when compared with control positive group as shown in Table (5). Daye et al. ${ }^{30}$ reported that glibenclamide suppressed the decrease in the body weight, while the suppression of weight loss in this study was achieved using polyherbal extracts. Chinwe et al. ${ }^{31}$ suggest that the Garcinia kola extract has shown to be a potential agent for the treatment of diabetes mellitus and restoration of body weight loss in alloxan induced diabetic rats. Furthermore, Shahadat et al. ${ }^{32}$ revealed that the final body weights of different treatments with plant extracts have showed significantly increased from the initial body weight.

Table 5: Effect of polyherbal leaves extracts on body weight

\begin{tabular}{|c|c|c|}
\hline Groups & Initial weight (g) & $\begin{array}{c}\text { Final weight (g) } \\
\text { After 5 weeks }\end{array}$ \\
\hline Group 1 & $27.30 \pm 0.21$ & $30.26 \pm 0.18$ \\
\hline Group 2 & $31.30 \pm 0.47$ & $23.97 \pm 0.23$ \\
\hline Group 3 & $30.76 \pm 0.23$ & $30.13 \pm 0.20$ \\
\hline Group 4 & $29.53 \pm 0.08$ & $28.60 \pm 0.05$ \\
\hline Group 5 & $31.30 \pm 0.37$ & $30.53 \pm 0.35$ \\
\hline Group 6 & $29.73 \pm 0.08$ & $28.26 \pm 0.12$ \\
\hline Group 7 & $28.66 \pm 0.14$ & $27.53 \pm 0.12$ \\
\hline LSD value & $0.811^{* *}$ & $0.614 * *$ \\
\hline & $* * 01)$. \\
\hline
\end{tabular}

\footnotetext{
Group 1: Control,

Group 2: Alloxan (150 mg kg),

Group 3: Diabetic mice + Metformin (150 mg kg),

Group 4: Diabetic mice + Polyherbal methanolic extract $(200 \mathrm{mg} \mathrm{kg})$,

Group 5: Diabetic mice + Polyherbal methanolic extract $(400 \mathrm{mg} \mathrm{kg})$,

Group 6: Diabetic mice + Polyherbal aqueous extract $(200 \mathrm{mg} \mathrm{kg})$,

Group 7: Diabetic mice + Polyherbal aqueous extract $(400 \mathrm{mg} \mathrm{kg})$.
}

\section{Conclusion}

Polyherbal methanolic extract contained relatively a higher amount of phenolic compounds and also exhibited a superior antioxidant activity, even comparable with the synthetic antioxidants (BHA). Furthermore, the extracts of polyherbal have antidiabetic effect on diabetic mice induced by alloxan, therefore could be taken as a dietary supplement as an anti-hyperglycaemic.
Conflict of Interest: The authors declared that present study was performed in absence of any conflict of interest.

\section{Source of Funding: Self}

Ethical Clearance: Ethical Committee for Research, Institute of Genetic Engineering and Biotechnology, University of Baghdad, Baghdad, Iraq. 


\section{References}

1. Rahimi M. A Review: Anti Diabetic medicinal plants used for diabetes mellitus. Bull. Env. Pharmacol. Life Sci. 2015; (4):163-180.

2. Rao MU, Sreenivasulu M, Chengaiah B, Reddy KJ, Chetty CM. Herbal Medicinesfor Diabetes Mellitus. International Journal of Pharm. Tech. Research. 2010; (2):1883-1892.

3. Kumar A, Goel MK, Jain RB, Khanna P, Chaudhary $\mathrm{V}$. India towards diabetes control: Key issues. Australasian Medical Journal. 2013; (6):524-531.

4. Bordoloi R, Dutta KN. A Review: Herbs Used in the Treatment of Diabetes mellitus. Journal of Pharmaceutical, Chemical and Biological Sciences. 2014; (2):86-92.

5. AL-Azawi AH. Phytochemical, Antibacterial and Antioxidant Activities of dodonea viscosa Jacq. extracts Cultivated in Iraq. Iraqi Journal of Biotechnology. 2017; 16 (4): 37-46.

6. Seebaluck-Sandoram R, Lall N, Fibrich B, Van Staden AB, Mahomoodally F. Antibioticpotentiation, antioxidant, cytotoxic, antiinflammatory and anti-acetylcholinesterase potential of Antidesma madagascariense Lam. (Euphorbiaceae). South African Journal of Botany. 2017; 111: 194-201.

7. Ibrahim AK, AL-Azawi AH. Hepatoprotective effect of (Arachis hypogeaL.) peanut skin extracts on CCl4induced liver damage in mice. Bioscience Research. 2018; 15(4): 3415-3428.

8. Hyun TK, Kim HC, Ko YJ, Kim JS. Antioxidant, $\alpha$-glucosidase inhibitory and anti-inflammatory effects of aerial parts extract from Korean crowberry (Empetrum nigrum var japonicum). Saudi J Biol Sci. 2016; 23:181-188.

9. Barut B, Barut EN, Engin S, Ozel A, Sezen FS. Investigation of the Antioxidant, $\alpha$-Glucosidase Inhibitory, Anti-inflammatory, and DNA Protective Properties of Vaccinium arctostaphylos L. Turkish Journal of Pharmaceutical Sciences. 2019; 16 (2): 175.

10. N'Guessan J.D, Bidie AP, Lenta BN, Weniger B, Andre P, Guina F. In vitro assays for bioactivityguided isolation of anti-salmonella and antioxidant compounds in Thon ninja sanguine flowers. Afr. J.
Biotechnology. 2007; 6: 1685-1689.

11. American Association of Cereal Chemists (AACC). Method 08-01. The Association St. Paul, M.N. 1984.

12. Jayaprakasha GK, Singh RP, Sakariah KK. Antioxidant activity of grape seeds (Vitis vinifera). Food Chem. 2001; 73:285-290.

13. Ogunmoyole T, Inaboya S, Makun JO, Kade IJ. Differential antioxidant properties of ethanol and water soluble phytochemicals of false nutmeg (Monodora myristica) seeds. Int $\mathrm{J}$ Biochem Biotechnol. 2013; 2: 253-262.]

14. Parasuraman S. Toxicological screening. J. Pharmacol. Pharmacother. 2011; 2: 74-79.

15. Syiem D, Khup P.Z. Study of Traditionally Used Medicinal Plants Osbeckia chinensis Linn for Hypoglycemic and Antihyperglycemic Effects in mice. Pharm. Biol. 2006; 44: 613-18.

16. SAS. Statistical Analysis System, User's Guide. Statistical. Version 9.1th ed. SAS. Inst. Inc. Cary. N.C. USA. 2012.

17. Pandey KB, Rizvi SI. Plant polyphenols as dietary antioxidants in human health and disease. Oxidative Medicine and Cellular Longevity. 2009; 2(5): 270278. doi: 10.4161/oxim.2.5.9498.

18. Raza AM, Anwar F, Shahwar D, Mumtaz WM, Danish M, Nazar FM, et al. Antioxidant and antiacetylcholine esterase potential of aerial parts of Conocarpus Erectus, Ficus Variegata and Ficus Maclellandii. Pak. J. Pharm. Sci. 2016; 29(2): 489495.

19. Lee YL, Jian SY, Lian PY, Mau JL. Antioxidant properties of extracts from a white mutant of the mushroom Hypsizigus marmoreus. J. Food Compos. Anal. 2008; 21: 116-124.

20. Hodge A, Sterner B. Toxicity Classes. In: Canadian Center for Occupational Health and Safety. 2005.

21. Shobana G, Devi GA, Keerthana K, John AAN, Jothi G, Hariharan G. Antidiabetic Potential of Ploy Herbal Formulation on Alloxan Induced diabetic. Int. Res. J. Pharm. 2018; 9 (8): 2230-8407.

22. Gulfraz M, Ahmad A, Asad MJ, Afzal U, Imran $\mathrm{M}$, Anwar $\mathrm{P}$, et al. Antidiabetic activities of leaves and root extracts of Justicia adhatoda Linn against alloxan induced diabetes in rats. African Journal of 
Biotechnology. 2011; 10(32): 6101-6106.

23. Latha S, Vijayakumar R. The Facts about Diabetes Mellitus- A Review. Galore International Journal of Health Sciences and Research. 2019; 4(2): 6475.

24. Gorzynik-Debicka M, Przychodzen P, Cappello F, Kuban-Jankowska A, Marino-Gammazza A, Knap N, et al. Potential health benefits of olive oil and plant polyphenols. International Journal of Molecular Sciences. 2018; 19 (3): 686-693. doi: 10.3390/ijms19030686.

25. Das SK, Samantaray D, Patra JK, Samanta L, Thatoi H. Antidiabetic potential of mangrove plants: a review. Frontiers in Life Science. 2016; 9(1): 7588.

26. Rao AV, GurfinkelDM. The bioactivity of saponins: triterpenoid and steroidal glycosides. Drug metabolism and drug interactions. 2000; 17(1-4): 211-236.

27. Arif T, Sharma B, Gahlaut A, Kumar V, Dabur R. Anti-diabetic agents from medicinal plants: A review. Chem Biol Lett. 2014; 1(1): 1-13.
28. Soman S, Rajamanickam C, Rauf AA, Indira M. Beneficial effects of Psidium guajava leaf extract on diabetic myocardium. Experimental and Toxicologic Pathology. 2013; 65(1-2): 91-95.

29. Mukhtar Y, Galalain AM, Yunusa UM. A Modern Overview on Diabetes Mellitus: A Chronic Endocrine Disorder. European Journal of Biology. 2019; 4(1): 1-14.

30. Daye C, Bin L, Yunhui L. Antihyperglycemic Effect of Ginkgo biloba Extract in StreptozotocinInduced Diabetes in Rats. BioMed Research International, 2013; Article ID 162724, pp.7.

31. Chinwe E, Uchechukwu D, Joel O, Linus O, Gladys O, Uchechukwu E. Estimation of Glucose Level and Body Weight in Alloxan Induced Diabetic Rat Treated with Aqueous Extract of Garcinia Kola Seed. Ulutas Medical Journal. 2015; 1(2): 26-30.

32. Shahadat MN, Islam R, Parvez MMM, Sarkar S. Antidiabetic Evaluations of some Traditional Plants in Alloxan Induced Diabetic Mice Model. IOSR Journal of Agriculture and Veterinary Science. 2019; 12(12): 59-68. 